\title{
Blockchain Technology-Based Good Distribution Practice Model of Pharmacy Industry in Indonesia
}

\author{
Erick Fernando ${ }^{1}$, Meyliana Meyliana ${ }^{1, *}$, Harco Leslie Hendric Spits Warnars ${ }^{2}$, Edi Abdurachman ${ }^{2}$, Surjandy Surjandy $^{1}$ \\ ${ }^{1}$ School of Information Systems, Information Systems Department, Bina Nusantara University, Jakarta, 11480, Indonesia \\ ${ }^{2}$ Department of Computer Science, BINUS Graduate Program-Doctor of Computer Science, Bina Nusantara University, Jakarta 11480, \\ Indonesia
}

\begin{tabular}{l} 
A R T I C L E I N F O \\
\hline Article history: \\
Received: 09 December, 2020 \\
Accepted: 27 February, 2021 \\
Online: 10 March, 2021
\end{tabular}

Keywords:

Blockchain Technology

Blockchain Pharmacy

Blockchain SCM

$C D O B$

$G D P$

\begin{abstract}
A B S T R A C T
Distribution is the main activity in integrated product supply chain management. In the pharmaceutical industry, the process of drug distribution is important because of the handling, storage, and distribution of medicinal products with good standards and quality. The problem that occurs in the pharmaceutical industry is the circulation of counterfeit drugs by related parties, for example, unofficial or unregistered distributors or data collection for unregistered medicines circulated by distributors. Permits misused from drug manufacturing processes until they are distributed or circulated do not comply with the Food and Drug Supervisory Agency standard provisions. These problems must be resolved quickly with technological support to facilitate the distribution process in recording data distribution, providing data security, and traceability of transactions between related parties. This study proposes a good drug distribution model by applying blockchain technology. The Model development uses a qualitative approach and a user center design. The result of this study is a validated drug distribution model with blockchain technology. The model has the characteristics of transparency, security, traceability, decentralization, automation, immutability, and reliability. This model can help the government ensure public health and safety by ensuring that the drugs received are of good quality, thereby increasing the community safety and health and trust in drugs in circulation.
\end{abstract}

\section{Introduction}

Supply chain management is a process that links suppliers to consumers [1]. The most important distribution process is the distribution process, namely contacting producers to consumers [1, 2]. Distribution encourages company profitability because of the impact of logistics costs incurred [3]. Distribution is the main activity in the integrated supply chain management of products. In the pharmaceutical industry, the process of drug distribution is important because of the handling, storage, and distribution of these products $[1,3]$. The distribution process has an entity involved and responsible for the distribution process to run properly. The distribution process in Indonesia already has a drug distribution process guideline in the regulations of the BPOM. Badan Pengawas Obat dan Makanan (BPOM) or English name Drug and Food Supervisor. Good drug distribution guidelines aim to ensure drug quality and identity during the distribution process [4]. Good distribution fulfills the responsibilities of entities

${ }^{*}$ Corresponding Author: Meyliana, Email: Meyliana@binus.edu involved in various aspects of the supply chain distribution process. Indonesia has made the pharmaceutical industry focus on the 2015-2035 national industrial development master plan (RIPIN) to improve peoples quality of life [5, 6]. The government also guarantees the availability of pharmaceuticals and medical devices according to Presidential Instruction number 6 of 2016 as an effort to improve health services in the context of national health insurance [7]. The vision and mission of national industrial development, various problems occur with the rampant distribution of counterfeit drugs by related parties, such as unofficial or unregistered distributors or unregistered records of drugs distributed by distributors properly and misuse of a permit from the process of making drugs to be distributed according to the standard provisions of the BPOM [8,9]. Apart from this, there is poor governance in the data collection of drugs and distributors registered at BPOM [10]. This is also reproduced in violations that occur in the sale of counterfeit and expired drugs, other types of drugs that should not be done in pharmacies [11]. The problem must be resolved quickly by identifying the parties involved in the 
drug distribution process in an integrated network so that it is easy to trace. Technology support is important to simplify the distribution process in recording data, providing data security, and traceability of transactions between related parties. This research proposes blockchain technology to be applied in the distribution process that occurs. Blockchain technology has the characteristics of transparency, security, traceability, decentralization, automation, immutability, reliability in carrying out the distribution process in the pharmaceutical industry [12]. This blockchain technology has been implemented in many industries [13]. Blockchain technology provides certainty in the validation of the distribution processes recorded and is well integrated with each other. This makes the tracking process easier to do to reduce theft, forgery, and increase data security $[14,15]$.

The last few years of research that has occurred have only provided a foundation for developing theories on information resource management in distributed virtual organizations. This study also does not fully regulate the supply chain process of the pharmaceutical industry but only evaluates the framework for the development and production processes [16, 17].

This research will focus on building a drug distribution model in the pharmaceutical industry using blockchain technology. The model built can improve the pharmaceutical industry distribution system, which is more integrated with one another so that it can be trusted, accountable, transparent, and protected from the circulation of counterfeit drugs [18]. The model can help the government ensure the community health and safety by ensuring the drugs received are of good quality, thereby increasing public trust.

\section{Theory}

\subsection{Supply chain Management}

Supply chain management is the management process of the materials used to create products, the production process, and the final products final delivery [19]. The management is made a chain that is tied to each other, and it can be said that the supply chain. Supply chain management that is carried out as a whole will be an added value that is effective and economical in running a business. The positive impact that occurs is the company is able to know and ensure a product made from good materials from suppliers, the production process to ensure that the product is made to arrive properly and with quality in the hands of consumers [20]. Supply chain management integrates various key processes in the company so that it aligns all activities from suppliers to customers to provide cost reduction and flexibility in activities [21].

\subsection{Value Chain}

The porter value chain is a value chain in which each activity will influence the each other to provide the companies competitive power or organization. Porter defines several five main activities, namely: incoming logistics, operations, outgoing logistics, marketing and sales, and services and support activities: procurement, technology development (including Research \& Development), human resource management, and infrastructure (planning systems, finance, quality, management information, etc.) $[22,23]$. The basic model of the Porter Value Chain Model is as follows:

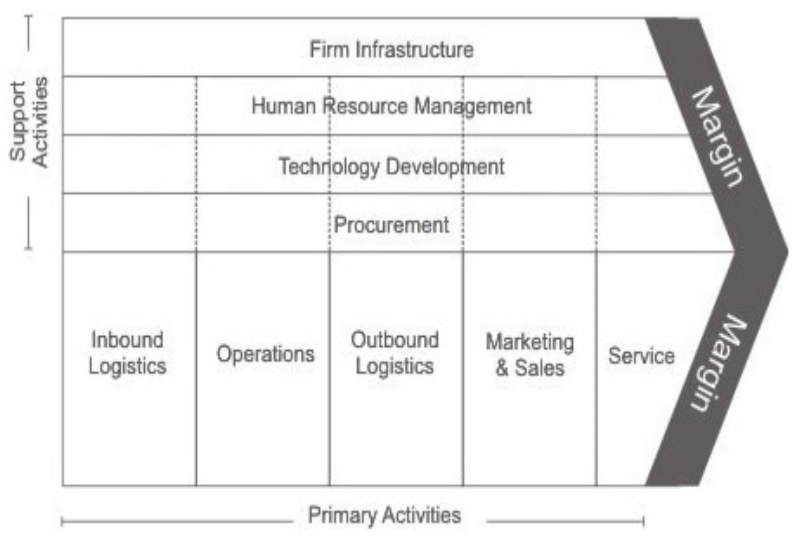

Figure 1: Value chain Porters [23]

\subsection{Blockchain}

Blockchain consists of the words block and chain, which can be interpreted as blocks that are tied in chains to one another. Satoshi Nakamoto first introduced blockchain in cryptocurrency $[24,25]$. Blockchain implements decentralized or distributed data storage. Blockchain has the characteristics of being immutable and append-only (can only be added). It is a distributed ledger, and all data is copied to network participants (nodes) [26, 27]. As time goes on, blockchain can be used in enterprise systems by providing a new touch in smart contracts [28]. Smart contracts are logic that is sequentially created by business processes to transact in the blockchain system based on an agreement between two people [26, 27].

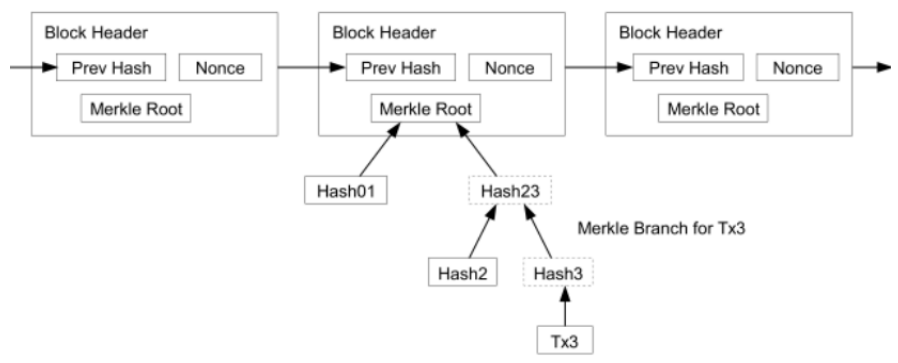

Figure 2. Blockchain [25]

\subsection{Good Distribution Practice}

Good distribution practice (GDP) or in Indonesian country called "Cara distribusi obat yang baik" (CDOB). Good drug distribution methods are used to ensure that drugs are consistently produced and controlled to achieve quality standards in accordance with the intended use and required in the distribution permit and product specifications.

\subsection{User-Centered Design (UCD)}

User-Centered Design (UCD) is a framework in doing design by looking at the users point of view, and it should be the users point of view $[28,29]$. This UCD has the following steps:

1. Context of use is done to get what the user wants.

2. User requirements are made to adjust the design to the wishes of the user

3. Design solutions to meet requirements are carried out to find solutions in making a design based on the needs of the user. 
4. Evaluation is the evaluation of the design from user feedback so that the design is appropriate.

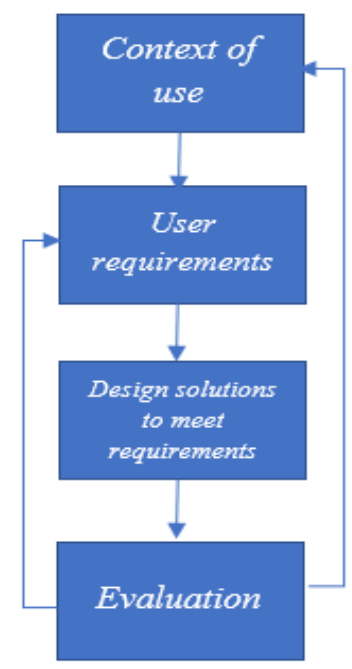

\section{Methodology}

This research methodology with a qualitative approach and user center design techniques. The constructed model is based on literature studies and focus group discussions (FGD) with the pharmaceutical industry. This FGD with 4 domain experts from the division related to the drug distribution process, including the logistics department, the finished drug warehouse, marketing and sales, Quality Control, and Quality Assurance. Discussions were carried out with experts with several opportunities to ensure that the models design was in accordance with the pharmaceutical industry needs. In this discussion process, the experts said they agreed with the model being developed. With this validated model, it is possible to be applied in the pharmaceutical industry.

\subsection{Context of Use}

This stage searches for problems in users related to the distribution process to the pharmaceutical industry, pharmaceutical wholesalers, and pharmacies. The problem finding was carried out with a forum discussion group on the pharmaceutical industry. This discussion forum was attended by marketing sales managers, the production planning and inventory control section, the finished drug warehouse. The problem that occurs is that many drug distribution processes that occur are not in accordance with government regulations. For example, there are still many pharmaceutical wholesalers that are not properly registered, drug distribution data are not well recorded, and each actor does not have integration. So, it requires technology that can handle problems. The author offers blockchain technology that is used to enable each related party to integrate data and information properly and record irreversible drug distribution data.

\subsection{User Requirements}

This stage will adjust the design to the wishes of the user by conducting interviews with a forum discussion group in related parties. From the interview results, each party has confirmed to agree to the model being developed. The model developed describes the distribution process well with blockchain technology.

\subsection{Design solutions to meet requirements.}

This stage re-validates the parties involved in the drug distribution process to get the distribution model built that meets the requirements.

\subsection{Evaluation}

Evaluate the design from user feedback so that the design is in accordance with conducting back interviews with a forum discussion group in related parties. In addition, this evaluation can also get a view of the model being developed.

\section{Analysis and Discussion}

The development of a good drug distribution model is carried out with a user-center design approach, which is carried out in several stages. This study discussion relates to the model developed with the literature and based on the guidelines for good drug distribution established by the Republic of Indonesia Food and Drug Administration. This model starts from the value chain (outbound logistics, distribution, marketing and sales, and service), related stakeholders (warehouses, distributors, hospitals/clinics/ pharmacies, drug stores, and end consumers/patients).

The blockchain technology that tells the data will be stored in the blockchain during the distribution process. Blockchain implementation in this distribution process begins in the pharmaceutical industry getting drug purchases from drug distributors and sending drugs back to distributors, and the data will be stored on the blockchain database, then the drug purchase process is also carried out by pharmacies, drug stores, and hospitals to distributors. The data will be stored in the blockchain. Consumers make drug purchases from pharmacies, drugstores, and hospitals. The data will be recorded in the blockchain database.

The last is the GDP Aspect in the industry, consisting of 9 aspects (quality management, management, personnel organizations, buildings and equipment, operations, selfinspection, complaints of drugs or presumed counterfeit drugs and process recall, transportation, distribution facilities based on contracts, documentation). The model developed can be seen in Figure 4.

The main business processes in the pharmaceutical industry are divided into 2 major areas, namely good manufacture practice (GMP) in Indonesia called "cara pembuatan obat yang baik" (CPOB) and Good distribution practice (GDP) in Indonesia called "cara distribusi obat yang baik" (CDOB). CPOB starts from the industry doing development and research on drugs that want to be produced. After that, purchase raw materials from suppliers and then make production. Production results will be stored in the finished drug warehouse. Meanwhile, CDOB starts from finished drugs ready for distribution to customers, from the pharmaceutical industry to pharmaceutical wholesalers, pharmaceutical wholesalers to health services (pharmacies, drug stores, hospitals). Further health services can distribute to the public. The complete picture of the $\mathrm{CPOB}$ and $\mathrm{CDOB}$ models can be seen in Figure 5.

\section{Discussion}

\subsection{Value chain}

This value chain starts from an industrial warehouse, a storage place for drugs produced and ready to be produced. Detail process distribution: 


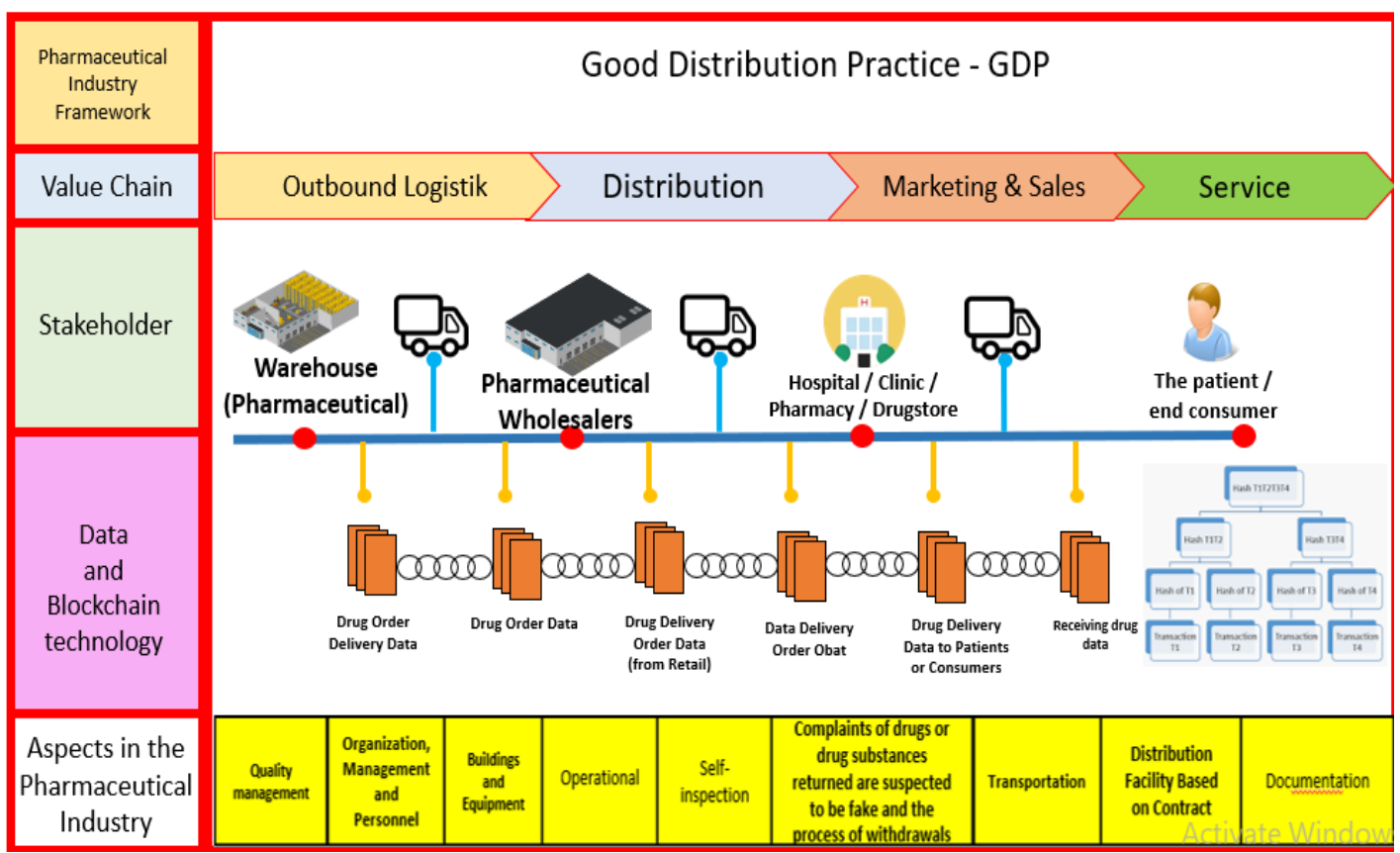

Figure 4: Good distribution Practice Model with Technology Blockchain

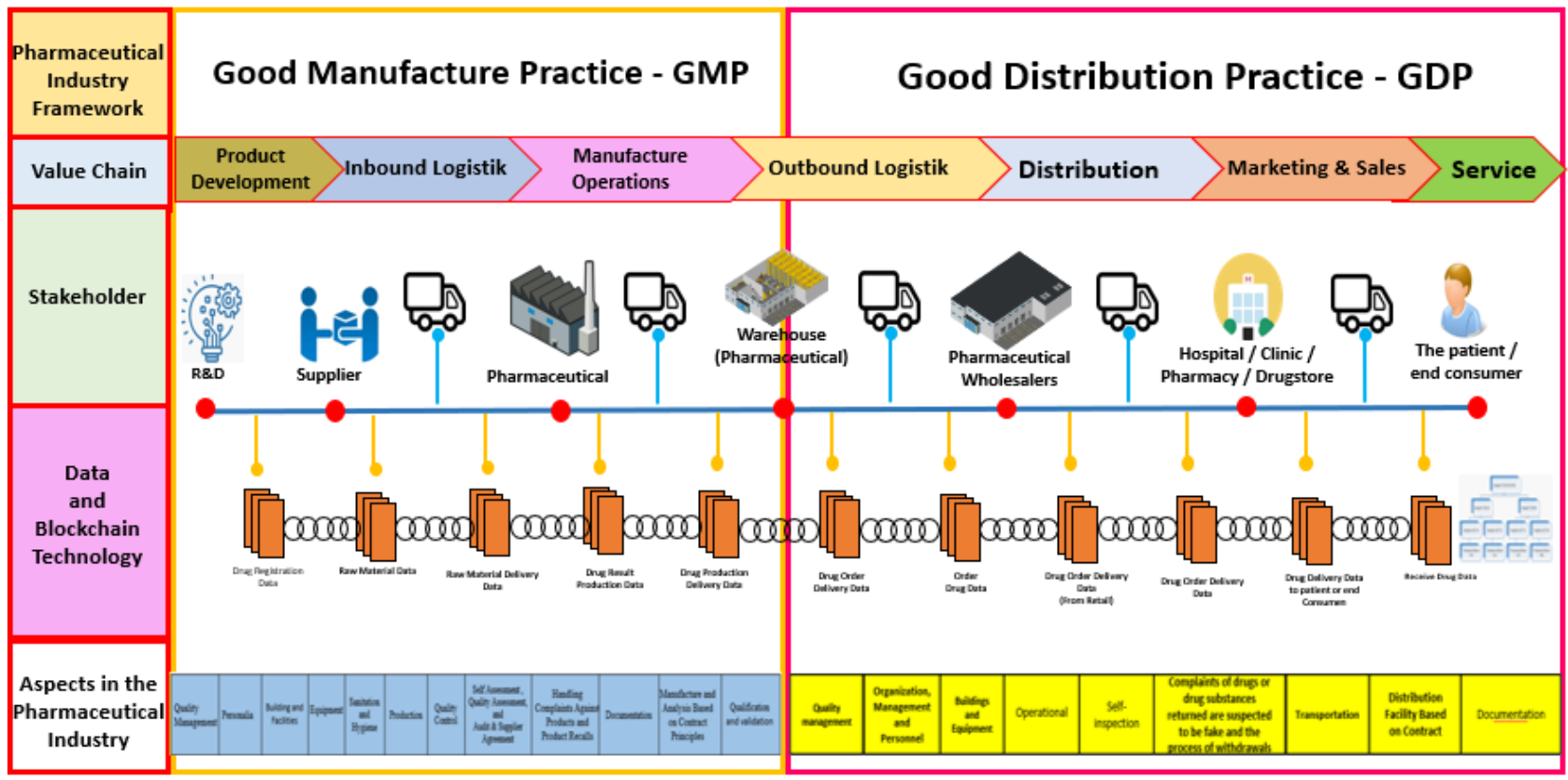

Figure 5: Good Manufacture Practice (GMP) and Good Distribution Practice Model with Technology Blockchain

Outbound logistics

Outbound logistics are activities that involve the distribution of finished products to customers. For example, sending an existing car via a service to car dealers is an outbound logistics activity. Inbound Logistics refers to the transportation, storage, and delivery of goods that enter the business. Outbound Logistics refers to the same for goods going out of business. Inbound and outbound logistics combine in supply chain management, as managers seek to maximize distribution network reliability and efficiency while minimizing transportation and storage costs. Understanding the differences and relationships between inbound and outbound logistics can help develop a comprehensive supply chain management strategy. 
Distribution

Distribution is a marketing activity carried out by distributors or intermediaries to deliver goods or services from producers to consumers. Delivery of goods can also be from the manufacturer, industry, or manufacturer to retailers or retailers.

Marketing and sales

Marketing acts as a think tank that designs product development and marketing strategies. Sales are a team implementing the promotional strategy to increase product sales.

Service

Service is done to keep Consumers can have the interest to Return to buy into a sale. Thus it is necessary to provide services to Consumers well and in accordance with the demands of Consumers.

\subsection{Stakeholder}

Stakeholders are parties involved in the distribution process in the pharmaceutical industry where there is a pharmaceutical industry (drug maker and provider), pharmaceutical wholesalers (who are parties who supply drugs to other parties, including the pharmaceutical traders themselves and retailers. Hospital/Clinic/Pharmacy/Drugstore) is a service facility provided by the government as a drug distributor to end consumers or patients. And most recently, consumers who use drugs later.

\subsection{Data and Blockchain Technology blockchain}

Transaction data that occurs during drug distribution in the pharmaceutical industry supply chain will be recorded into the blockchain system to ensure data can be stored safely and adequately and accessed by parties tied to this drug distribution network.

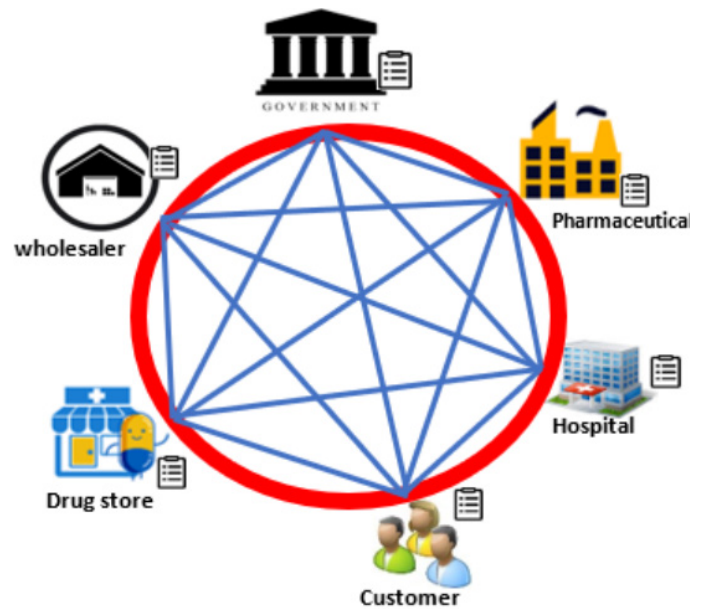

Figure 6: Pharmacy distribution model with blockchain [30]

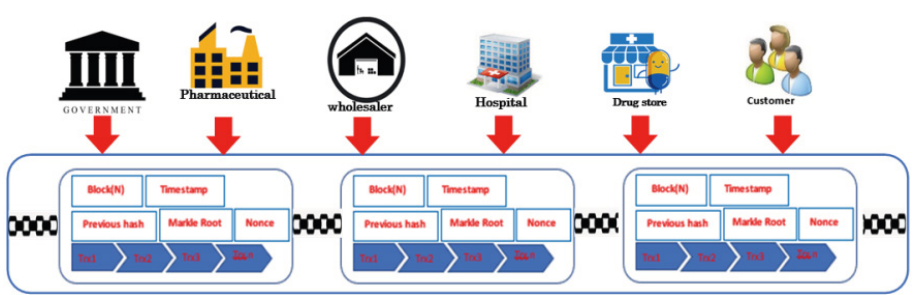

Figure 7: Transaction model distribution of pharmaceutical drugs with blockchain [30].
- Timestamp, which is when the block is created in

- UNIX time, which is the number of seconds that it has

- applies when the block is formed.

- Distribution data, namely the number of distribution processes carried out on each party.

- Node ID, namely the identity of the node, which is the public key of existing nodes.

- Prev. Hash is the hash of the previous block.

\subsection{Aspect in the pharmaceutical industry}

The drug distribution process needs to be maintained and controlled to provide good quality drugs and in accordance with the standards set by the government. This can meet the health and safety of the community. For this reason, this quality can be maintained with a guideline for good drug distribution based on Regulation of the Drug and Food Supervisory Agency Number 9 of 2019 concerning Technical Guidelines for Good Drug Distribution Methods [4] including:

\section{Quality Management.}

The quality system developed must be completely documented and monitored for its effectiveness. There must be a control system in the system changes covering the principles of quality risk management.

2. The organization, management, and personnel.

Implementation and management of a good quality management system as well. The correct distribution of drugs and/or drug substances is very dependent on the personnel who run it. There must be sufficient and competent personnel to carry out all tasks responsible for the distribution facility. Management must appoint a person in charge of the distribution facility. According to the laws and regulations, the person in charge must be a pharmacist who meets the qualifications and competencies. The pharmacist who gets delegation is obliged to report the activities carried out to the person in charge. The person in charge has duties, including:

\section{Buildings and equipment}

Buildings and equipment to ensure the protection and distribution of drugs and/or medicinal substances. Buildings shall be designed and adapted to ensure that good storage conditions are maintained, have adequate safety, sufficient capacity to allow proper storage and handling of drugs, and that storage area are equipped with adequate lighting to enable all activities to be carried out accurately and safely.

\section{Operations.}

All actions taken by distribution facilities must ensure that the identity of drugs and/or medicinal ingredients is not lost. Their distribution is handled according to the specifications listed on the packaging. Distribution facilities must use all available devices and methods to ensure that the source of drugs and/or drug 
ingredients received comes from the pharmaceutical industry and/or other distribution facilities with licenses in accordance with statutory regulations to minimize the risk of drugs/or counterfeit drugs ingredients. Enter the official distribution chain.

\section{Self-inspection}

Self-inspection must be carried out to monitor implementation and compliance with $\mathrm{CDOB}$ compliance and follow up on necessary corrective steps.

6. Complaints on drugs and or returned drug ingredients, suspected to be fake and withdrawn.

All complaints and other information about potentially defective drugs should be collected, reviewed, and investigated according to written procedures. The responsible personnel must approve drugs to be resold in accordance with their respective authority.

\section{Transportation.}

The transportation process must apply adequate transportation methods. Medicines must be transported under storage conditions according to the information on the packaging. Appropriate transportation methods should be used, including transportation by land, sea, air, or a combination of the above. Whatever transportation is chosen, it must ensure that the drug does not undergo changes in conditions during transportation, which can reduce quality. A risk-based approach should be used when planning transportation routes.

\section{Facility-based on the contract.}

All contract activities must be in writing between the contract giver and contract accepter, and each activity must comply with the $\mathrm{CDOB}$ requirements.

\section{Documentation.}

Good documentation is an important part of a quality management system. Written documentation should be clear to prevent oral communication errors and facilitate tracing, among other things, batch history, instructions, and procedures.

\section{Conclusion}

This study analyzes the application process of blockchain technology in the pharmaceutical industry in the distribution process. The process carried out shows that the application of blockchain technology helps the process carried out in the process of drug distribution carried out from the pharmaceutical industry (drug warehouse), which is distributed to distributors and retailers to consumers. Blockchain helps record all transactions that occur from related parties. Transactions that are recorded will be ensured by the characteristics of the blockchain, namely immutable, distributed, and ensuring data security from irresponsible attacks. With another guarantee from blockchain technology, there is traceability of transactions that occur. After developing a good drug distribution model with blockchain, we will build a prototype to prove the model described can be used by the pharmaceutical industry.

\section{Conflict of Interest}

The authors declare no conflict of interest.

\section{Acknowledgment}

This work is partially supported by the Directorate General of Strengthening for Research and Development of Research, Technology, and Higher Education, the Republic of Indonesia as part of Penelitian Dasar Unggulan Perguruan Tinggi". Research Grant to Binus University entitled "Pemanfaatan Teknologi blockchain pada manajemen rantai pasok Industri farmasi untuk mendukung Good Manufacturing Practice" with contract number: 12/AKM/PNT/2019 and contract date: 27 March 2019. The authors also gratefully acknowledge the reviewers helpful comments and suggestions, which have improved the presentation.

\section{Reference}

[1] W. Chung, T. W. NG, "The Roles of Distributor in the Supply Chain - Pushpull Boundary," International Journal of Business and Management, 3(7), $28-39,2008$.

[2] R. Whewell, Supply Chain in the Pharmaceutical Industry, Gower Publishing Limited, 2010.

[3] X. Yang, "A review of distribution related problems in logistics and supply chain research," International Journal of Supply Chain Management, 2(4), $1-8,2013$.

[4] Badan POM RI, Petunjuk Pelaksanaan Cara Distribusi Obat yang Baik, 2015.

[5] Republik Indonesia, "Peraturan Pemerintah Republik Indonesia Nomor 14 Tahun 2015 Tentang Rencana Induk Pembangunan Industri Nasional 2015 2035," 1-51, 2015.

[6] Tempo.co, Airlangga: Industri Daur Ulang Topang Implementasi Ekonomi Berkelanjutan - bisnis Tempo.co, 2018.

[7] Presiden Republik Indonesia, Instruksi Presiden (INPRES) tentang Percepatan Pengembangan Industri Farmasi dan Alat Kesehatan, 2016.

[8] Health.detik.com, Soal Peredaran Obat Palsu di Apotek, Pengusaha Sentil Pengawasan BPOM, 2019.

[9] Bisnis.com, Ini Pemicu Merosotnya Pertumbuhan Industri Farmasi, 2016.

[10] Badan Pengawas Obat dan Makanan, Cek Produk BPOM - Innisfree, 2017.

[11] Kompas.com, BPOM: Terjadi Peningkatan Temuan Produk Farmasi Ilegal Kompas.com, 2016.

[12] E. Fernando, R. Kosala, E. Abdurachman, "Key Factor Adoption Blockchain Technology In Smart Supply Management: Literature Review Erick," in 2018 International Seminar on Research of Information Technology and Intelligent Systems (ISRITI) Key, 99-102, 2018.

[13] F. Casino, T.K. Dasaklis, C. Patsakis, "A systematic literature review of blockchain-based applications: Current status, classification and open issues," Telematics and Informatics, 36, 55-81, 2019, doi:10.1016/j.tele.2018.11.006.

[14] M.G. Moniveena, T.M.P. Kumar, "An overview of track \& trace regulations in pharma industry and its impact on the reverse logistics of medicines- status in regulated countries and India," International Journal of Pharmaceutical Sciences Review and Research, 47(2), 85-91, 2017.

[15] R. Rotunno, V. Cesarotti, A. Bellman, V. Introna, M. Benedetti, "Impact of track and trace integration on pharmaceutical production systems," International Journal of Engineering Business Management, 6(1), 1-11, 2014, doi:10.5772/58934.

[16] S. Chen, R. Shi, Z. Ren, J. Yan, Y. Shi, J. Zhang, "A Blockchain-Based Supply Chain Quality Management Framework," Proceedings - 14th IEEE International Conference on E-Business Engineering, ICEBE 2017 Including 13th Workshop on Service-Oriented Applications, Integration and Collaboration, SOAIC 207, 172-176, 2017, doi:10.1109/ICEBE.2017.34.

[17] X. Wu, Y. Lin, "Blockchain recall management in pharmaceutical industry," Procedia CIRP, 83, 590-595, 2019, doi:10.1016/j.procir.2019.04.094.

[18] T.K. Mackey, G. Nayyar, "A review of existing and emerging digital technologies to combat the global trade in fake medicines," Expert Opinion on Drug Safety, 16(5), 587-602, 2017, doi:10.1080/14740338.2017.1313227.

[19] E. Fernando, Surjandy, H.L.H.S. Warnars, Meyliana, R. Kosala, E. Abdurachman, "Critical Success Factor of Information Technology Implementation in Supply Chain Management: Literature Review," Proceedings - 2018 5th International Conference on Information Technology, Computer and Electrical Engineering, ICITACEE 2018, 315-319, 2018, doi:10.1109/ICITACEE.2018.8576979.

[20] J.T. Mentzer, J.S. Keebler, N.W. Nix, C.D. Smith, Z.G. Zacharia, "Defining Supply Chain Management," Journal of Business Logistics, 22(2), 1-25, 2001, doi:10.1002/j.2158-1592.2001.tb00001.x.

[21] E. Corbin, "Supply Chain Management Practices and Intermediation: Puerto 
Rican Pharmaceutical Wholesalers," Supply Chain Forum: International Journal, 10(1), 32-43, 2009, doi:10.1080/16258312.2009.11517206.

[22] M. Porter, Creating and sustaining competitive advantage: Management logics, business models, and entrepreneurial rent, 1985, doi:10.1007/978-3319-54540-0.

[23] M. Porter, "Five Forces Model that Shape Strategy," Havard Business Riview, 89(1/2), 62-77, 2010

[24] H.-H. Buerger, Ethereum White Paper, Github.Com, 2016.

[25] S. Nakamoto, "Bitcoin: A Peer-to-Peer Electronic Cash System," Www.Bitcoin.Org, 9, 2008, doi:10.1007/s10838-008-9062-0.

[26] M. Swan, Blockchain for Business: Next-Generation Enterprise Artificial Intelligence Systems, 1st ed., Elsevier Inc., 2018, doi:10.1016/bs.adcom.2018.03.013.

[27] M. Swan, O'Reilly - Blockchain. Blueprint for a New Economy - 2015, First Edit, O'Reilly Media, Inc., United States of America, 2015.

[28] T. Lowdermilk, User-Centered Design, O'Reilly Media, Inc., 1005 Gravenstein Highway North, Sebastopol, CA 95472, 2013.

[29] E.G. Perdomo, M.A.T. Cardozo, C.A.C. Perdomo, R.R. Serrezuela, "A revieew of the user based web design: Usability and information architecture," International Journal of Applied Engineering Research, 12(21), 11685-11690, 2017.

[30] E. Fernando, Meyliana, H.L.H.S. Warnars, E. Abdurachman, "BLOCKCHAIN TECHNOLOGY FOR PHARMACEUTICAL DRUG DISTRIBUTION IN INDONESIA : A PROPOSED MODEL," ICIC Express Letters, 14(2), 1-8, 2020. 